\title{
Total Lactic Acid Bacteria and Antibacterial Activity in Yoghurt with Addition of Ananas comosus Merr. and Cinnamomum burmannii
}

\author{
Lusia Yotista Enggal Parasthi, Diana Nur Afifah*, Choirun Nissa, Binar Panunggal
}

\begin{abstract}
Background: Diarrhea is a gastrointestinal disorder which is the second leading cause of death in children under five years. Food and beverage contamination is the biggest cause of diarrhea in developing countries. Honey cream pineapple (Ananas comosus Merr.) and cinnamon (Cinnamomum burmannii) have antibacterial properties that can inhibit the growth of Escherichia coli and Salmonella typhi causing diarrhea.

Objective: This study aims to analyze the total differences of Lactic Acid Bacteria (LAB) and antibacterial activity in yoghurt with the addition of honey cream pineapple and cinnamon extract.

Methods: The study was an experimental study with various treatments in adding honey cream pineapple $(0 \%, 20 \%, 40 \%$, and $60 \%$ ) and cinnamon extract (4\% and 6\%). Total LAB was calculated using the Total Plate Count (TPC) method and antibacterial activity was tested using Kirby Bauer method.

Results: There was no significant difference in yoghurt with the addition of honey cream pineapple and cinnamon extract. Yoghurt with the highest $L A B$ was the one with $40 \%$ addition of honey cream pineapple and $6 \%$ of cinnamon extract (N40M2) with total LAB $1,43 \times 10^{19} \mathrm{CFU} / \mathrm{ml}$. The results of the antibacterial activity showed no significant difference of inhibition zone against $\mathrm{S}$. typhi, while there was significant difference of inhibition zone against $E$. coli. The highest activity against S. typhi was yoghurt with $60 \%$ addition of honey cream pineapple and $4 \%$ of cinnamon extract (N60M1) resulting $6,81 \mathrm{~mm}$ inhibition zone and the highest activity against $E$. coli was N40M1 resulting 6,77 $\mathrm{mm}$ of inhibition zone.

Conclusion: Total $L A B$ yoghurt with the addition of honey cream pineapple and cinnamon extract have met FAO and Indonesian National Standards with $\mathrm{LAB}$ minimum $10^{7} \mathrm{CFU} / \mathrm{ml}$. Antibacterial activity of all yoghurt treatments categorized as medium inhibition (5-10 $\mathrm{mm}$ ).
\end{abstract}

Keywords: antibacterial activity, cinnamon, honey cream pineapple, total Lactic Acid Bacteria (LAB), yoghurt

\author{
*Correspondence: \\ d.nurafifah.dna@fk.undip.ac.id \\ Diana Nur Afifah \\ Department of Nutrition Science, Faculty of Medicine, Universitas Diponegoro, Semarang, Indonesia
}

\section{INTRODUCTION}

Diarrhea is a digestive disease that relates to loose and watery bowel movements more than three times a day. ${ }^{1}$ This disease is the second leading cause of child mortality, which kills around 525,000 children under five per year. ${ }^{2}$ Based on The Health Research data in 2018 , there were $12.3 \%$ episodes of diarrheal disease in children under five. ${ }^{3}$ Diarrhea leads to dehydration for more than $10 \%$ of body mass, the decrease in absorption of nutrients and food intake, and the increase in the catabolism of nutrient reserves and death. ${ }^{4}$ Furthermore, nutritional deficits early in life might cause mental and physical growth disorders. ${ }^{5}$

Escherichia coli and Salmonella typhi are the most common bacterias that cause diarrhea on children under five. ${ }^{6}$ Physiologically, E. coli is a facultative gramnegative bacterium which accounts for $0.1 \%$ of the gastrointestinal microbiota. ${ }^{7}$ Yet this bacterium may be pathogenic if contains a large amount of pathogenic $E$. coli which cause disease especially for hosts with immune deficits. This bacterium causes diarrhea through various pathways based on the strain by producing enterotoxigenic, intestinal cell invasion and membrane adhesion. 8

On the other hand, Salmonella typhi is a gramnegative bacterium Salmonella $\mathrm{sp}$ which causes typhoid fever, severe diarrhea, and small intestine perforation. ${ }^{9}$ E. coli and Salmonella are acid-sensitive enteric pathogens. ${ }^{10,11}$ However, several factors such as polysaccharide capsules in $E$. coli and high gastric $\mathrm{pH}$ due to certain food sources can protect them from acidic condition in gastrointestinal tract. ${ }^{12,13}$

Non-pathogenic microorganisms are required to prevent the development of enteric pathogens that can withstand from gastric acidity. ${ }^{14}$ Probiotics are nonpathogenic microorganism that can maintain the balance of the gut microbiota. Lactic acid bacteria (LAB) is a probiotic that produces bacteriocins and lactic acid which can inhibit the growth of pathogenic bacteria. ${ }^{15}$ One of the functional beverage products containing probiotics from the LAB group with a high sales rate $(75 \%)$ is yoghurt. ${ }^{16}$ Yoghurt is a beverage which is easily absorbed that may boost digestive health from intestinal 
diseases such as constipation ${ }^{17}$, diarrhea ${ }^{18}$, colitis ${ }^{19}$, and colon cancer. ${ }^{20}$ Streptococcus thermophilus and Lactobacillus bulgaricus are LAB with mutualism symbiosis and are used as a standard for yoghurt starter. ${ }^{21,22}$

Yoghurt can be made from cow's milk, goat's milk, skimmed milk, soy milk, and a combination of these milk. Goat milk was used in this study because it contained higher protein, essential vitamins, phenolic compounds, less alpha casein, and was easier to digest than cow's milk. ${ }^{23}$ However, the presence of capric fatty acids, caprylic fatty acids, and caproic fatty acids that are easily evaporated can enhance the distictive smell of

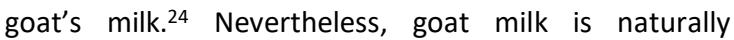
homogenized because it has smaller fat globules that makes it easier to digest than cow's milk. ${ }^{25}$ The addition of honey cream pineapple and cinnamon on goat's milk are intented to decrease the smell and increase the nutrient content, $L A B$, and antibacterial activity of the yoghurt product. ${ }^{26}$

Glucose on the honey cream pineapple is used by $L A B$ as the main carbon source to produce lactic acid. ${ }^{24}$ Honey cream pineapple extract had an antibacterial effect to prevent bacteria from sticking on the intestinal mucose due to bromelain as the active compound. ${ }^{27}$ Other than that, cinnamon had an antibacterial effect as it contains essential oil that can inhibit the growth of bacteria. ${ }^{28}$ Those compounds have antibacterial effect both on gram-negative and positive bacteria such as LAB which is needed to produce yoghurt. ${ }^{29,30}$ So far, the previous studies just focus on testing the total $L A B$ in soyghurt with honey cream pineapple extract added. ${ }^{31}$ So this research focus on testing the total LAB with honey cream pineapple extract and cinnamon added.

\section{METHODS}

This research was a complete randomized experimental study (CRD) withthe addition of honey cream pineapple at $0 \%, 20 \%, 40 \%, 60 \%$ and cinnamon extract at $4 \%$ and $6 \%$ in the yoghurt formulas. Each test was carried out 3 times in duplicate. This study focused on the LAB total test and antibacterial activity which was carried out at the Central Laboratory of the Diponegoro National Hospital, Semarang. The ingredients used in this study were fresh goat milk as the main ingredient for making yoghurt, honey cream pineapple, cinnamon extract, and other ingredients such as $0.85 \% \mathrm{NaCl}$ solution, MRSA (de Man Rogosa Sharpe Agar), MHA
(Mueller Hinton Agar), Escherichia coli and Salmonella typhi bacteria culture. Fresh goat milk was obtained from Pedurungan Tengah while the honey cream pineapple was obtained from Banyumanik, Semarang. Meanwhile, cinnamon was obtained from Banyumanik Semarang traditional market. Based on the results of the determination carried out at the Ecology and Biosystematic Laboratory of Diponegoro University, the honey cream pineapple (Ananas comosus Merr.) used has thinner and smoother skin also sweeter taste than ordinary pineapples. In this study we used the pineapple pulp and the log of cinnamon which had an aromatic smell and was brown in color which was originally from Indonesia (Cinnamomum burmanii). ${ }^{32}$ The equipments used in this study were blender, temperature thermometer, pan, stove, filter press cloth, incubator, petri dishes, pipettes, paper discs and Vernier-caliper.

Making Yoghurt Formulations with The Addition of Honey Cream Pineapple and Cinnamon Extract

Preliminary research by making yoghurt formulations with the addition of honey cream pineapple and cinnamon extract was carried out at the Diponegoro University Integrated Laboratory. We used a fresh and perfectly ripe honey cream pineapple to make the pineapple extract. Next steps were peeling off, washing, cutting, and steaming the honey cream pineapple pineapple for \pm 15 minutes at $90^{\circ} \mathrm{C}$. After that, blended the honey cream pineapple without water and filtered it from the pulp to get the extraction. We did the same steps to make the cinnamon extract, (without blending the cinnamon). Meanwhile, to make the yoghurt, we started to pasteurize fresh goat milk at $61^{\circ} \mathrm{C}-63^{\circ} \mathrm{C}$ then added subcultures of Streptococcus thermophilus and Lactobacillus bulgaricus at $5 \%$ of the milk. Next, we added honey cream pineapple extract at $0 \%, 20 \%, 40 \%, 60 \%$ to the yoghurt formulation as mention on table 1 ) and cinnamon extract at $4 \%$ and $6 \%$. We evenly stirred all the samples, then incubated them in an incubator for \pm 5 hours at $37^{\circ} \mathrm{C}$. This study used 8 yoghurt samples namely (NOM1, NOM2, N20M1, N2OM2, $\mathrm{N} 40 \mathrm{M} 1, \mathrm{~N} 40 \mathrm{M} 2, \mathrm{~N} 60 \mathrm{M} 1$ and $\mathrm{N} 60 \mathrm{M} 2$ ) with the addition of honey cream pineapple and cinnamon and also 1 sample of plain yoghurt. The negative control used in the total $L A B$ test and antibacterial activity was sterile distilled water. Positive control for the total LAB test was plain yoghurt. Meanwhile, the positive control for the analysis of antibacterial activity was chloramphenicol.

Table 1. Yoghurt treatment sample with the addition of honey cream pineapple and cinnamon extract (per $1 \mathrm{~L}$ of goat milk)

\begin{tabular}{cccc}
\hline Treatment & \% pineapple & \% cinnamon extract & \% milk+starter \\
\hline NOM0 & 0 & 0 & 100 \\
NOM1 & 0 & 4 & 96 \\
NOM2 & 0 & 6 & 94 \\
N20M1 & 20 & 4 & 76 \\
N20M2 & 20 & 6 & 74 \\
N40M1 & 40 & 4 & 56 \\
N40M2 & 40 & 6 & 54 \\
N60M1 & 60 & 4 & 36 \\
N60M2 & 60 & 6 & 34 \\
\hline
\end{tabular}




\section{Analysis of Total Lactic Acid Bacteria (LAB) dan Antibacteria Activity}

The total LAB test was carried out using the Total Plate Count (TPC) method to determine the amount of LAB contained in yoghurt. One $\mathrm{ml}$ of sample was diluted in $9 \mathrm{ml}$ of $0.85 \% \mathrm{NaCl}$ solution. Pipette was used to put the diluted sample into a sterile petri dish and sterile MRSA (de Man Rogosa Sharpe Agar) was added to each sterile petri dish. After the jelly freezed, the petri dishes were incubated in an incubator at $37^{\circ} \mathrm{C}$ for $24-48$ hours. The total colonies of lactic acid bacteria (LAB) were calculated using the SPC (Standard Plate Count) method in units of $\mathrm{CFU} / \mathrm{ml}$. Based on FAO and SNI standards, yoghurt must contain a minimum of $\mathrm{LAB} 10^{7} \mathrm{CFU} / \mathrm{ml} .^{33}$ Antibacterial activity tests were carried out using the Kirby Bauer method or disc diffusion. ${ }^{34}$ This method was used to see the response of bacterial growth inhibition based on the diameter of the clear zone sample against Escherichia coli and Salmonella typhi. The test step started by pouring MHA (Mueller Hinton Agar) media into a sterile petri dish. Shortly after the media solidified, the pathogenic bacteria suspense was evenly rubbed onto the media surface. Then the disc paper soaked in the yoghurt sample was placed (next placed the disc paper that had soaked in the yoghurt sample) on surface of the MHA media with a little pressure so that it adhered perfectly. Incubation of MHA media was at $37^{\circ} \mathrm{C}$ for 18-24 hours. Then, the diameter of the clear area/inhibition zone was measured around the disc paper using a caliper. The zone of inhibition was categorized based on the clear zone diameter, which were weak if it was $\leq 5 \mathrm{~mm}$, moderate if between 5-10 $\mathrm{mm}$, strong if between $10-19 \mathrm{~mm}$, and very strong if it was $20 \mathrm{~mm}$ or more.

\section{Data Analysis}

The data collected in this study were primary data. Total LAB and antibacterial activity against $E$. coli and S. typhi bacteria were analyzed using the SPSS 20 for windows computer program with the Kruskal Wallis statistical test with a $95 \%$ level of confidence.

\section{RESULTS AND DISCUSSION}

\section{Total Lactic Acid Bacteria (LAB)}

The addition of honey cream pineapple and cinnamon to yoghurt did not show significant differences in the total LAB with $p$ value of $0.947 \quad(p>0.05)$. Nevertheless, the total value of $L A B$ in all samples still meet the requirements on the number of probiotic bacteria in fermentation products according to the Indonesian National Standard and FAO which is at least $10^{7} \mathrm{CFU} / \mathrm{ml} .{ }^{33}$ It is due to mutualism symbiosis from both LABs that is used. L. bulgaricus produced amino acids, valine, glycine, and histidine which stimulate the growth of $S$. thermophilus. Meanwhile, $S$. thermophilus produces formic acid, pyruvic acid, $\mathrm{CO}_{2}$ and folic acid which supports the growth of L. bulgaricus. S. thermophilus is a homofermentative LAB which produces lactic acid as the main product. S. thermophilus is the only species of bacteria in the genus Streptococci that produces the enzyme lactase. The beneficial effect of $S$. thermophilus is by producing a lactase enzyme to digest lactose in milk. This symbiosis has a positive impact on the yoghurt product so that LAB couldreproduce well. ${ }^{22}$

Based on Figure 1, there was a decrease in the total LAB for the NOM1 and NOM2 treatments. The decrease in total LAB could be caused by essential oils in cinnamon which acts as antibacterial agents as they contains active compounds including cinnamaldehyde, eugenol, saponins, and tannins. ${ }^{28}$ The antibacterial properties of active compounds in essential oils works to break cell walls, damaged plasma membranes and membrane proteins. It causes cell leakage, and binds enzymes in the cell wall and oxygen which is needed by bacteria so that bacterial growth could be inhibited or died. ${ }^{37}$ Cinnamaldehyde at $0.2 \%$ reduces $>3-\log \mathrm{CFU} / \mathrm{ml}$ of the total LAB. ${ }^{38}$

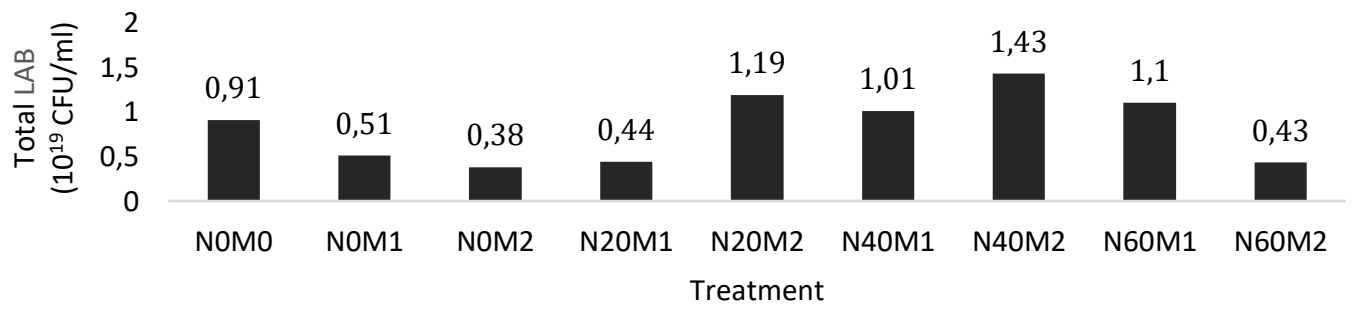

Information:

NOMO $=100 \%$ yoghurt with a ratio of honey cream pineapple and cinnamon extract 0\%:0\%

NOM1 $=96 \%$ yoghurt with a ratio of honey cream pineapple and cinnamon extract $0 \%: 4 \%$

NOM2 $=94 \%$ yoghurt with a ratio of honey cream pineapple and cinnamon extract $0 \%: 6 \%$

N2OM1 $=76 \%$ yoghurt with a ratio of honey cream pineapple and cinnamon extract $20 \%: 4 \%$

$\mathrm{N} 20 \mathrm{M} 2=74 \%$ yoghurt with a ratio of honey cream pineapple and cinnamon extract $20 \%: 6 \%$

N40M1 $=56 \%$ yoghurt with a ratio of honey cream pineapple and cinnamon extract $40 \%: 4 \%$

$\mathrm{N} 40 \mathrm{M} 2=54 \%$ yoghurt with a ratio of honey cream pineapple and cinnamon extract $40 \%: 6 \%$

$\mathrm{N} 60 \mathrm{M} 1=36 \%$ yoghurt with a ratio of honey cream pineapple and cinnamon extract $60 \%: 4 \%$

$\mathrm{N} 60 \mathrm{M} 2=34 \%$ yoghurt with a ratio of honey cream pineapple and cinnamon extract $60 \%: 6 \%$

Graph 1. The results of total LAB analysis for yoghurt with the addition of honey cream pineapple and cinnamon 
Meanwhile, there was an increase in the total LAB for the N20M1, N2OM2, and N40M2 treatments. The increase is due to the addition of honey cream pineapple that contains simple sugar such as glucose $2.32 \%$, fructose $1.42 \%$, and sucrose $7.89 \%$. Sucrose is broken down by LAB into fructose and glucose which is used to obtain energy so that they supported the growth of LAB. ${ }^{24}$ This is in accordance with the previous research on yoghurt with different sucrose variations which showed that the higher sucrose concentration, the more total LAB is produced. ${ }^{39}$
LAB reduction occurred in the N60M1 and N60M2 treatments. This might be caused by the less percentage of milk contained in yoghurt. Lactose content in milk may have a positive effect on the growth of LAB. The addition of lactose in the fermentation process increases the growth rate of $L A B$. Lactose is the main carbon that could be broken down by LAB into glucose and galactose which are converted into lactic acid. ${ }^{40}$ Goat milk itself has $4.7 \%$ lower lactose than cow milk, so the main carbon source that could be used by bacteria is also less. ${ }^{41}$

Table 2. Results of Antibacterial Activity Analysis

\begin{tabular}{ccc}
\hline \multirow{2}{*}{ Treatment } & \multicolumn{2}{c}{ Bacterial Inhibition Zone Diameter (mm) } \\
\cline { 2 - 3 } & S. typhi & E. coli \\
NOM0 & $5.33 \pm 0.58$ & $5.17 \pm 0.29$ \\
NOM1 & $6.00 \pm 0.50$ & $5.33 \pm 0.58$ \\
N20M1 & $6.17 \pm 0.58$ & $6.10 \pm 0.17$ \\
N20M2 & $5.67 \pm 0.58$ & $6.27 \pm 0.25$ \\
N40M1 & $6.10 \pm 0.53$ & $6.43 \pm 0.12$ \\
N40M2 & $6.03 \pm 0.87$ & $6.77 \pm 0.25$ \\
N60M1 & $6.50 \pm 0.87$ & $6.63 \pm 0.29$ \\
N60M2 & $6.87 \pm 0.60$ & $6.33 \pm 0.29$ \\
$P$ & $6.17 \pm 0.76$ & $5.50 \pm 0.87$ \\
\end{tabular}

\footnotetext{
*Testing with the Kruskal Wallis test; ${ }^{1}$ significance $>0.05,{ }^{2}$ significance $<0.05$

Information:

NOMO $=100 \%$ yoghurt with a ratio of honey cream pineapple and cinnamon extract 0\%:0\% NOM1 $=96 \%$ yoghurt with a ratio of honey cream pineapple and cinnamon extract $0 \%: 4 \%$ NOM2 $=94 \%$ yoghurt with a ratio of honey cream pineapple and cinnamon extract 0\%:6\% $\mathrm{N} 20 \mathrm{M} 1=76 \%$ yoghurt with a ratio of honey cream pineapple and cinnamon extract $20 \%: 4 \%$ $\mathrm{N} 20 \mathrm{M} 2=74 \%$ yoghurt with a ratio of honey cream pineapple and cinnamon extract $20 \%: 6 \%$ $\mathrm{N} 40 \mathrm{M} 1=56 \%$ yoghurt with a ratio of honey cream pineapple and cinnamon extract $40 \%: 4 \%$ $\mathrm{N} 40 \mathrm{M} 2=54 \%$ yoghurt with a ratio of honey cream pineapple and cinnamon extract $40 \%: 6 \%$ $\mathrm{N} 60 \mathrm{M} 1=36 \%$ yoghurt with a ratio of honey cream pineapple and cinnamon extract $60 \%: 4 \%$ $\mathrm{N} 60 \mathrm{M} 2=34 \%$ yoghurt with a ratio of honey cream pineapple and cinnamon extract $60 \%: 6 \%$
}

The total percentage of cinnamon and honey cream pineapple in the N60M1 and N60M2 treatments was greater than the percentage of milk. Honey cream pineapple and cinnamon have antibacterial agents against gram-negative and gram-positive bacteria, so they could inhibit the growth of LAB. ${ }^{29,30}$ The studies of antibacterial on cinnamon extract against several bacteria showed that gram-positive bacteria were more sensitive than gram-negative bacteria. ${ }^{42}$ Meanwhile, the antibacterial on honey cream pineapple could also inhibit gram-positive bacteria, such as flavonoids and polyphenols because they had the same polar properties as peptidoglycan which made up the cell walls of grampositive bacteria. ${ }^{29}$

The higher percentage of honey cream pineapple than milk causes the sugar concentration in yoghurt to be excessive. The sucrose contained in honey cream pineapple has high solubility, the ability to reduce the relative humidity balance and bind water, so that it could be used in food preservation. Concentrated medium concentrations with high levels of sucrose might cause osmosisin which water in the bacterial cell comes out through the membrane and flows into the sugar solution. This event causes the bacteria to experience plasmolysis. ${ }^{43} \mathrm{As}$ a result, the water content contained in yoghurt decreases. The low water content in yoghurt could also inhibit the growth of LAB. ${ }^{39}$

Water activity $\left(a_{w}\right)$ is closely related to the availability of water and not to foodstuffs. Water content is important for the growth of $L A B$ in the fermentation process. Water is used by $L A B$ as a medium for transporting nutrients into cells, removing metabolites from outside cells, where enzymatic reactions took place, as a medium for cellular complement synthesis, and plays a role in helping biochemical processes such as hydrolyzing polymers into monomers. Based on previous research on yoghurt with the addition of honey cream pineapple and cinnamon, the average water content contained was around $80 \%$. Meanwhile, the water content in yoghurt according to Indonesian National Standard 2981:2009 was 83-84\%.

LAB growth phase consisted of a lag phase, an exponential phase, a stationary phase, and a death phase. At 4 to 10 hours there was a growth phase where bacterial growth took place very rapidly. The next phase occured at 11 to 14 hours where there was no increase of the number of bacteria because the number of cells grew was the same as the dead cells. The death phase of LAB occured from the 15th hour where the number of bacteria began to decline because the nutrients in the 
media and energy reserved in the cells began to run low. Research conducted on $L A B$ stored at room temperature showed a decrease in the number of $L A B$ after incubation for 6 hours. Researchers had controlled to inhibit LAB mortality gradually by storing yoghurt in the refrigerator temperature immediately after the incubation process at 5 hours when LAB was still in growth phase. Probiotic products stored at $4^{\circ} \mathrm{C}$ had shown to maintain stable bacterial counts for 28 days.
However, the limitation of this study was that the refrigerator did not have a temperature thermometer. The laboratory performed temperature control (40C) manually using a thermometer every 3 months, while the research was carried out in the third month after checking the temperature. This allowed the active phase of $L A B$ growth due to the increase in temperature in the refrigerator.

Table 3. Results of the Advanced Antibacterial Activity Test E. coli

\begin{tabular}{llllllllll}
\hline Perlakuan & NOM0 & NOM1 & NOM2 & N20M1 & N20M2 & N40M1 & N40M2 & N60M1 & N60M2 \\
\hline NOM0 & - & 0.796 & $0.043^{*}$ & $0.046^{*}$ & $0.034^{*}$ & $0.046^{*}$ & $0.043^{*}$ & $0.043^{*}$ & 0.796 \\
NOM1 & 0.796 & - & 0.099 & 0.072 & $0.034^{*}$ & $0.046^{*}$ & $0.043^{*}$ & 0.068 & 0.796 \\
NOM2 & $0.043^{*}$ & 0.099 & - & 0.346 & $0.034^{*}$ & $0.046^{*}$ & 0.068 & 0.239 & 0.500 \\
N2OM1 & $0.046^{*}$ & 0.072 & 0.346 & - & 0.121 & 0.077 & 0.178 & 0.637 & 0.369 \\
N20M2 & $0.034^{*}$ & $0.034^{*}$ & $0.034^{*}$ & 0.121 & - & 0.121 & 0.480 & 0.317 & 0.114 \\
N40M1 & $0.046^{*}$ & $0.046^{*}$ & $0.046^{*}$ & 0.077 & 0.121 & - & 0.487 & 0.105 & 0.072 \\
N40M2 & $0.043^{*}$ & $0.043^{*}$ & 0.068 & 0.178 & 0.480 & 0.487 & - & 0.261 & 0.116 \\
N60M1 & $0.043^{*}$ & 0.068 & 0.239 & 0.637 & 0.317 & 0.105 & 0.261 & - & 0.239 \\
N60M2 & 0.796 & 0.796 & 0.500 & 0.369 & 0.114 & 0.072 & 0.116 & 0.239 & - \\
\hline
\end{tabular}

Testing with Mann Whitney; *real difference (<0.05)

Information:

$\mathrm{NOMO}=100 \%$ yoghurt with a ratio of honey cream pineapple and cinnamon extract 0\%:0\%

NOM1 $=96 \%$ yoghurt with a ratio of honey cream pineapple and cinnamon extract 0\%:4\%

NOM2 $=94 \%$ yoghurt with a ratio of honey cream pineapple and cinnamon extract 0\%:6\%

$\mathrm{N} 20 \mathrm{M} 1=76 \%$ yoghurt with a ratio of honey cream pineapple and cinnamon extract $20 \%: 4 \%$

$\mathrm{N} 20 \mathrm{M} 2=74 \%$ yoghurt with a ratio of honey cream pineapple and cinnamon extract $20 \%: 6 \%$

$\mathrm{N} 40 \mathrm{M} 1=56 \%$ yoghurt with a ratio of honey cream pineapple and cinnamon extract $40 \%: 4 \%$

$\mathrm{N} 40 \mathrm{M} 2=54 \%$ yoghurt with a ratio of honey cream pineapple and cinnamon extract $40 \%: 6 \%$

$\mathrm{N} 60 \mathrm{M} 1=36 \%$ yoghurt with a ratio of honey cream pineapple and cinnamon extract $60 \%: 4 \%$

$\mathrm{N} 60 \mathrm{M} 2=34 \%$ yoghurt with a ratio of honey cream pineapple and cinnamon extract $60 \%: 6 \%$

\section{Antibacteria Activity}

The addition of honey cream pineapple and cinnamon to yoghurt did not show significant differences in antibacterial activity against $S$. typhi ( $p>0.05)$. Otherwise, there was a significant difference in antibacterial activity against $E$. coli $(p<0.05)$. However, the inhibition zone formed in $S$. typhi and $E$. coli was still in the moderate category (diameter 5-10 mm). The larger the inhibition zone, the greater the yoghurt ability to inhibit the growth of pathogenic bacteria. ${ }^{35}$ The low inhibition zone formed could be due to the more complex structure of the gram-negative bacterial cell wall, which has an outer layer in the form of lipoproteins, the thick middle layer called peptidoglycan, and a layer in lipopolysaccharides. This complex cell wall could inhibit antibacterial compounds from $L A B$, honey cream pineapple, and cinnamon to penetrate bacterial cell membranes. ${ }^{46}$

The highest inhibition zone against $\mathrm{S}$. typhi bacteria was in the N60M1 treatment of $6.87 \mathrm{~mm}$ and against $E$. coli in the $\mathrm{N} 40 \mathrm{M} 1$ treatment of $6.77 \mathrm{~mm}$. This was due to the antibacterial effect on the added honey cream pineapple. Pineapple contains a protease called bromelain as well as several compounds such as polyphenols, saponins, and flavonoids which are known as antimicrobial agents. The active compounds that work against gram-negative bacteria are bromelain and saponins. Bromelin is a proteolytic enzyme that plays a role in inducing the proteins breakdown of the bacterial membrane that weaken the cell walls and causing leakage to cell death. ${ }^{29}$ In addition, saponins play role to change the structure and function of the membrane, disrupt tension of the cell walls surface, and allow antibacterial substances easily entering cell. ${ }^{47}$

Further test results in Table 2, showed that there was a difference in the treatment of NOMO with NOM2, N2OM1, N20M2, N40M1, N40M2, N60M1, and N60M2 on the antibacterial activity against $E$. coli. These differences ae due to the addition of honey cream pineapple and cinnamon as antibacterial that inhibitsed the growth of $E$. coli. However, there was no difference between NOMO and NOM1 also between M1 and M2 treatments in all groups. The extraction process of cinnamon using water solvent at temperature of $90^{\circ} \mathrm{C}$ decrease the antibacterial agent compound. Cinnamon contains several main flavonoids known as antibacterial agent, such as cinnamaldehyde, cinnamylacetate, eucalyptol, and eugenol as the main phenol. ${ }^{48}$ Previous studies showed the highest flavonoid levels were found in the maceration method, namely extraction using organic solvents at cold temperature. ${ }^{49}$ Compounds of the flavonoid group were not heat resistant so boiling too long could damage the flavonoid compounds in cinnamon. ${ }^{50}$

There is an increase on antibacterial activity against $E$. coli with the addition of honey cream pineapple and cinnamon. In addition, $L A B$ in yoghurt produces other compounds besides lactic acid, namely bacteriocin and hydrogen peroxide which are also known as antibacterial agent. ${ }^{51}$ The main target of 
bacteriocins is to damage the permeability of the bacterial cytoplasmic membrane cell by forming pores on the membrane cell and eliminating the proton motive force. $L A B$ could also inhibit the growth of pathogenic bacteria. Lactic acid produced by LAB has a bactericidal effect on pathogenic bacteria so the $\mathrm{pH}$ decreased to 34.5.52 Meanwhile $E$. coli survived in acidic conditions up to $\mathrm{pH} 4.4$ and S. typhi at $\mathrm{pH} 4-9 .{ }^{11} \mathrm{pH}$ checks were carried out by researchers on the incubated yoghurt which showed $\mathrm{pH} 5$. The limitation of this study was the use of $\mathrm{pH}$ measuring device using litmus paper, while $\mathrm{pH}$ meter could read the measurement results more accurately than litmus paper..$^{53}$

Based on the results of the total LAB test, all yoghurt treatments with the addition of honey cream pineapple and cinnamon extract were suitable to eat because they fit the Indonesian National Standard and FAO yoghurt standards. All treatments also had antibacterial potential as diarrhea prevention based on antibacterial activity tests. However, the inhibition against S. typhi and E. coli was still in the moderate category.

\section{CONCLUSION}

Total $L A B$ in yoghurt with the addition of honey cream pineapple and cinnamon extract showed no significant difference $(p<0.05)$. The highest total $L A B$ in $\mathrm{N} 40 \mathrm{M} 2$ treatment was $1.42 \times 1019 \mathrm{CFU} / \mathrm{ml}$. Total LAB for all treatments was $1019 \mathrm{CFU} / \mathrm{ml}$. The results of the yoghurt antibacterial activity test did not show any difference against $S$. typhi $(p>0.05)$ but showed a difference against $E$. coli $(p<0.05)$. The antibacterial activity of all yoghurt treatments was categorized as a moderate inhibition $(5-10 \mathrm{~mm})$. The highest antibacterial activity against $S$. typhi was in the N60M1 treatment and against $E$. coli in the N4OM1 treatment.

\section{ACKNOWLEDGMENT}

All authors have no conflict of interest in this article. This research was funded by the Ministry of Research, Technology and Higher Education.

\section{REFERENCES}

1. World Health Organization. Diarrhoeal Disease Fact Sheet. (2017).

2. Barr, W. \& Smith, A. Acute Diarrhea in Adults. Am Fam Physician 89, 180-189 (2014).

3. Kementrian Kesehatan Republik Indonesia. Hasil Riset Kesehatan Dasar 2018. (2018).

4. Brown, K. H. Symposium : Nutrition and Infection, Prologue and Progress Since 1968 Diarrhea and Malnutrition. Am. Soc. Nutr. Sci. 328-332 (2003).

5. Keusch, G. T. et al. Diarrheal Diseases. in Disease Control Priorities in Developing Countries (eds. Jamison, D., Breman, J. \& Measham, A.) (Oxford University Press, 2006).

6. Saeed, A., Abd, H. \& Sandstrom, G. Microbial aetiology of acute diarrhoea in children under five years of age in Khartoum, Sudan. J. Med. Microbiol. 64, 432-437 (2015).
7. Eckburg, P. B. et al. Diversity of the Human Intestinal Microbial Flora. Science (80-. ). 308, 1635-1638 (2005).

8. Rodrigues, J. F., Piazza, R. M. F., Ferreira, L. C. S. \& Martinez, M. B. Diarrheagenic Escherichia coli. Brazilian J. Microbiol. 47, 3-30 (2016).

9. Näsström, E. et al. Salmonella typhi and Salmonella paratyphi A elaborate distinct systemic metabolite signatures during enteric fever. elife Sci. 3, 1-19 (2014).

10. Hidayah, N. Review Article Salmonella : A foodborne pathogen. Int. Food Res. J. 473, 465473 (2011).

11. World Health Organization. E.coli Fact Sheet. (2018).

12. Corbett, D. \& Roberts, I. S. Capsular Polysaccharides in Escherichia coli. in Advances in Applied Microbiology 65, 1-26 (Elsevier, 2008).

13. Koseki, S., Mizuno, Y. \& Sotome, I. Modeling of Pathogen Survival during Simulated Gastric Digestion. Appl. Environ. Microbiol. 77, 10211032 (2011).

14. Katouli, M. Population structure of gut Escherichia coli and its role in development of extra-intestinal infections. 2, 59-72 (2010).

15. Sanders, M. E. et al. Safety assessment of probiotics for human use. Gut Microbes 1, 164185 (2010).

16. Rul, F. Yoghurt: microbiology, organoleptic properties and probiotic potential. in Fermented Food - Part II: Technological Interventions 418450 (CRC Press, 2017).

17. Mirghafourvand, M., Rad, A. H., Mohammad, S., Charandabi, A. \& Shokri, K. The Effect of Probiotic Yoghurt on Constipation in Pregnant Women : A Randomized Controlled Clinical Trial The Effect of Probiotic Yoghurt on Constipation in Pregnant Women : A Randomized Controlled Clinical Trial. Iran Red Crescent Med J. 18, (2016).

18. Choudhary, M., Sharma, D. \& Beniwal, M Traditional Yoghurt and Probiotic in Treatment of Acute Childhood Diarrhoea : A Blinded Randomized Controlled Non - Inferiority Trial. J. Pediatr. Neonatal Care 2, 1-7 (2015).

19. Baroja, M. L. \& Kirjavainen, P. V. Antiinflammatory effects of probiotic yoghurt in inflammatory bowel disease patients. 1, 470479 (2007).

20. Pala, V. et al. Yoghurt consumption and risk of colorectal cancer in the Italian European Prospective Investigation into Cancer and Nutrition cohort. 2719, 2712-2719 (2011).

21. CoI, J. D., Travaglia, F., Piana, G., Capasso, M. \& Arlorio, M. Euterpe oleracea juice as a functional pigment for yoghurt. 38, 893-897 (2005).

22. Rachman, S. D., Djajasoepena, S., Kamara, D. S., Idar, I. \& Sutrisna, R. Kualitas Yoghurt yang Dibuat dengan Kultur Dua (Lactobacillus bulgaricus, Streptococcus thermophilus dan Lactobacillus acidophilus) dan Tiga Bakteri (Lactobacillus bulgaricus, Streptococcus 
thermophilus, dan Lactobacillus acidophilus). Chem. Nat. Acta 3, 76-79 (2015).

23. Vinderola, C. G., Mocchiutti, P. \& Reinheimer, J. A. Interactions Among Lactic Acid Starter and Probiotic Bacteria Used for Fermented Dairy Products. J. Dairy Sci. 85, 721-729 (2002).

24. Insyiroh, U., Budi, S. \& M, A. Nilai pH, Keasaman, Citarasa, dan Kesukaan Susu Fermentasi dengan Penambahan Ekstrak Buah Nanas. J. Apl. Teknol. Pangan 3, 114-116 (2014).

25. Clark, S., Barbara, M. \& M.A, G. A 100-Year Review : Advances in Goat Milk Research 1. 10026-44 (2017).

26. Kusumawati, I., Purwanti, R., Afifah, D.N. Analisis Kandungan Gizi dan Aktivitas Antioksidan pada yoghurt dengan Penambahan Nanas Madu (Ananas comosus Mer.) dan Ekstrak Kayu Manis (Cinnamomum burmanni). Journal of Nutrition College. 8, 196-206 (2019).

27. Pohan, L. Ekstraksi Minyak Kelapa Sawit dengan Menggunakan Enzim Bromelin Nenas [skripsi]. Masyarakat Perkelapa-Sawitan Indonesia (Institut Pertanian Bogor, 2002).

28. Herdwiani, W. \& Rejeki, E. S. Determination of Cytotoxic Activity from Cinnamon Stem Bark for T47D Cell Culture. J. Farm. Indones. 12, 102-113 (2015).

29. Zharfan, R. \& Mustika, A. Antimicrobial Activity of Pineapple (Ananas comosus L. Merr) Extract against Multidrug-resistant of Pseudomonas aeruginosa : An In Vitro Study. Indones. J. Trop. Infect. Dis. 6, 118-123 (2017).

30. Sayuti, A. I., Umayah, E. \& Puspitasari, E. Uji Aktivitas Antibakteri Kombinasi Minyak Atsiri Lempuyang Wangi (Zingiber aromaticum Val.) dan Bangle (Zingiber cassumunar Roxb.) terhadap Bakteri Staphylococcus aureus dan Escherichia coli. Artikel Ilmiah Hasil Penelitian Mahasiswa (Universitas Jember, 2014).

31. Wardani, E. K., Zulaekah, S. \& Purwani, E. Pengaruh Penambahan Sari Buah Nanas (Ananas comosus) terhadap Jumlah Bakteri Asam Laktat (BAL) dan Nilai pH Soyghurt. J. Kesehat. 10, 68-74 (2017).

32. Starr, F., Starr, K. \& Loope, L. Cinnamomum burmannii. Hawaiian Ecosystems at Risk Project (HEAR), United States Geological Survey, Biological Resources Division Halekala Field Station, Maui (2003). Available at: http://www.hear.org/Pier/pdf/pohreports/cinn amomum_burmannii.pdf. (Accessed: 16 Juni 2019)

33. Food and Agriculture Organization of the United Nations. Codex stan 243-2003: Standard for fermented milks. in Milk and Milk Products 1-11 (2010).

34. Sacher, R. A., McPherson, R.A. Tinjauan Klinis Hasil Pemeriksaan Laboratorium. 11th ed. (Penerbit EGC Buku Kedokteran, 2004).

35. El, T. Reliability of Kirby-Bauer Disk Diffusion Method for Detecting Carbapenem Resistence in Acinetobacter baumanni-calcoaceticus. Antimicrob Agents Chemother. 57, (2013).
36. Misnadiarly, D. Mikrobiologi untuk klinik dan laboratorium. (Penerbit Rineka Cipta, 2014).

37. Kong, X., Liu, X., Li, J. \& Yang, Y. Advances in Pharmacological Research of Eugenol. Curr Opin Complement Altern Med. 1, 8-11 (2014).

38. Gann, L. D. Antimicrobial Activity of Essential Oils and Their Components Against Lactic Acid Bacteria. (The University of Tennessee, 2013).

39. Agustine, L., Okfrianti, Y. \& Jumiyati. Identifikasi Total Bakteri Asam Laktat (BAL) pada Yoghurt dengan Variasi Sukrosa dan Susu Skim. J Dunia Gizi. 1, 79-83 (2018).

40. Rahmadi, A. Bakteri Asam Laktat dan Mandai Cempedak. Bayu, editor. (Mulawarman University Press, 2019).

41. Guo, M. Goat Milk. In: Caballero B, editor. Encyclopedia of Food Sciences and Nutrition. 2nd ed. (Academic Press, 2003).

42. Shan, B., Cai, Y., Rooks, J. \& Orke, H. Antibacterial Properties and Major Bioactive Components of Cinnamon Stick (Cinnamomum burmannii): Activity against Foodborne Pathogenic Bacteria. J Agric Food Chem. 55, 5484-90 (2007).

43. Gianti, I., Evanuarini, H. Pengaruh Penambahan Gula dan Lama Penyimpanan terhadap Kualitas Fisik Susu Fermentasi. J IImu dan Teknol Has Ternak. 6, 28-33 (2011).

44. Mardalena. Fase Pertumbuhan Isolat Bakteri Asam Laktat (BAL) Tempoyak Asal Jambi yang Disimpan Pada Suhu Kamar. J Sain Peternak Indones. 11, 58-66 (2016).

45. Trisnawita, Y., Silalahi, J. \& Sinaga, S. M. The Effect of Storage Condition on Viability of Lactic Acid Bacteria in Probiotic Product. Asian J Pharm Clin Res. 11, 84-6 (2018).

46. Pelczar, M. J., Chan, E. Dasar-dasar Mikrobiologi. (Penerbit UI Press, 2009).

47. Karlina, C. Y., Ibrahim, M. \& Trimulyono, G. Aktivitas Antibakteri Ekstrak Herba Krokot (Portulaca oleracea L.) terhadap Staphylococcus aureus dan Escherichia coli. Lentera Bio Unesa. 2, 87-93 (2005).

48. Shen, Y., Jia, L., Honma, N., Hosono, T. \& Ariga, $T$. Beneficial Effects of Cinnamon on the Metabolic Syndrome, Inflammation, and Pain, and Mechanisms Underlying These Effects - A Review. J Tradit Complement Med. 2, 27-32 (2011).

49. Damar, A. C., Runtuwene, M. R. J. \& Wewengkang, D. S. Kandungan Flavonoid dan Aktivitas Antioksidan Total Ekstrak Etanol Daun Kayu Kapur (Melanolepsis multiglandulosa Reinch f). J Ilm Farm Unstrat. 3, 11-21 (2014).

50. Chaaban, H., loannou, I. \& Christine, G. Effect of heat processing on thermal stability and antioxidant activity of six flavonoids. J Food Process Preserv. 1-12 (2017).

51. Fauziah, P. N., Nurhajati, J. \& Crysanti. Daya Antibakteri Filtrat Asam Laktat dan Bakteriosin Lactobacillus Bulgaricus dalam Soygurt terhadap Pertumbuhan Klebsiella pneumonia. Bionat J Ilmu Hayati \& Fisik. 15, 132-138 (2013). 52. Sablon, E., Contreras, B. \& Vandamme, E. 
Antimicrobial Peptides of Lactic Acid Bacteria : Mode of Action, Genetics, and Biosynthesis. In: Scheper T, editor. Advances in Biochemical Engineering/Biotechnology. (Springer, 2000).
53. Coninck, V, De., Keller, E. X., Doizi, S. \& Audouin, M. Evaluation of a Portable Urinary pH Meter and Reagent Strips. J Eudourology. 32, (2018). 